\title{
ERRATUM
}

\section{Erratum to: Emergence Delirium in Pediatric Anesthesia}

\author{
Arthura D. Moore ${ }^{1}$ Doralina L. Anghelescu ${ }^{1}$
}

Published online: 26 April 2017

(C) Springer International Publishing Switzerland 2017

\section{Erratum to: Pediatr Drugs (2017) 19:11-20 \\ DOI 10.1007/s40272-016-0201-5}

In the original version, Reference 55 was published incorrectly.

Reference 55, which previously read:

55. Khattab AM, El-Seify ZA, Shaaban A, Radojevic D, Jankovic I. Sevoflurane-emergence agitation: effect of supplementary lowdose oral ketamine premedication in preschool children undergoing dental surgery. Eur $J$ Anaesthesiol. 2010;27(4):353-8.

should read:

55. Khattab AM, El-Seify ZA. Sevoflurane-emergence agitation: effect of supplementary low-dose oral ketamine premedication in preschool children undergoing dental surgery. Saudi J Anaesth. 2009;3:61-6.

The former article was retracted from the European Journal of Anaesthesiology in 2011 as it was found to be a duplicate of the article published in the Saudi Journal of Anaesthesia.

The online version of the original article can be found under doi:10.1007/s40272-016-0201-5.

Doralina L. Anghelescu

doralina.anghelescu@stjude.org

1 Department of Pediatric Medicine, Division of

Anesthesiology, MS 130, St. Jude Children's Research

Hospital, 262 Danny Thomas Place, Memphis, TN 38105,

USA 